\begin{tabular}{|c|c|}
\hline Title & $\begin{array}{l}\text { Repair of Rabbit Osteochondral Defects by an A cellular Technique with an UItrapurified A Iginate Gel Containing } \\
\text { Stromal Cell-Derived Factor-1 }\end{array}$ \\
\hline Author(s) & Sukegawa, A tsushi; I wasaki, Norimasa; Kasahara, Y asuhiko; Onodera, Tomohiro; Igarashi, Tatsuy a; Minami, A kio \\
\hline Citation & $\begin{array}{l}\text { Tissue Engineering Part A , 18(9-10), } 934945 \\
\text { https://doi.org/10.1089/ten.tea.2011.0380 }\end{array}$ \\
\hline Issue Date & 2012-05-01 \\
\hline Doc URL & http:/hdl.handle.net/2115/49281 \\
\hline Rights & $\begin{array}{l}\text { This is a copy of an article published in the Tissue Engineering Part A @ } 2012 \text { ○ Mary A nn Liebert, Inc.; T issue } \\
\text { Engineering Part A is available online at: http:/www.liebertonline.com. }\end{array}$ \\
\hline Tyре & article \\
\hline File Information & TEA 18-9-10_934-945.pdf \\
\hline
\end{tabular}

Instructions for use 


\title{
Repair of Rabbit Osteochondral Defects by an Acellular Technique with an Ultrapurified Alginate Gel Containing Stromal Cell-Derived Factor-1
}

\author{
Atsushi Sukegawa, M.D., Norimasa Iwasaki, M.D., Ph.D., Yasuhiko Kasahara, M.D., Ph.D., \\ Tomohiro Onodera, M.D., Ph.D., Tatsuya Igarashi, M.D., Ph.D., and Akio Minami, M.D., Ph.D.
}

The objective of this study was to determine whether the local administration of stromal cell-derived factor-1 (SDF-1) using ultrapurified alginate gel (UPAL gel) could improve reparative tissues of osteochondral defects compared with those without treatment. For the investigation, a full-thickness osteochondral defect $4.5 \mathrm{~mm}$ in diameter and $3 \mathrm{~mm}$ in depth was created in the patella groove of the distal femur in rabbits. Local expression of SDF-1 protein was temporarily upregulated at 1 week after creating the osteochondral defect. The local administration of SDF-1 enhanced the migration of host cells, mainly bone marrow stromal cells (BMSCs), to the site of the osteochondral defect. In vitro cell migration assay supported this result. In the SDF-1 (UPAL gel containing SDF-1) treatment group, the histological scores and the compressive modulus of reparative tissues were significantly improved compared with the no-treatment and vehicle (UPAL gel without SDF-1) groups. On the other hand, SDF-1 did not influence the cellular proliferation and chondrogenesis of BMSCs. Based on the results obtained here, we speculate that SDF-1 enhances the reparative process of osteochondral injuries not through direct effects on the behavior of host cells, but through increased migration of host cells to the injured site. UPAL gel, as a vehicle material, may play an important role in chondrogenesis of recruited cells, mainly BMSCs. The cell-free approach with local administration of SDF-1 may be an effective strategy for developing a minimally invasive technique for cartilage tissue regeneration.

\section{Introduction}

$\mathbf{T}$ HE VERY POOR CAPABILITY of articular cartilage for selfrepair means that surgical procedures are required to treat cartilaginous lesions. ${ }^{1-4}$ Cartilage tissue engineering, which is also referred to as autologous chondrocyte implantation (ACI), is an ideal procedure for such lesions. Since the first clinical report by Brittberg et al., ${ }^{5}$ a number of authors have demonstrated successful clinical outcomes of this procedure for cartilaginous lesions. ${ }^{6-14}$ However, prospective randomized trials have suggested no apparent superiority of this procedure over other surgical options for the repair of osteochondral defects. ${ }^{15-18}$

One of the possible reasons for the unexpected outcome is the adverse effects resulting from the invasive procedures used in the current $\mathrm{ACI}$ technique. The current technique requires a two-stage operation. The first stage is to harvest normal cartilage tissue to isolate chondrocytes. The second one is to implant the isolated cells cultured for 2-5 weeks into the osteochondral defect with periosteal coverage. Further, these processes necessitate a wide arthrotomy for cellular implantation and further exposure to harvest the periosteum. ${ }^{17,19-21}$
To prevent adverse effects related to the invasive procedures, a novel cellular implantation system without the need for periosteal coverage, and which can be arthroscopically performed, must be established. For this purpose, we developed an in situ forming gel based on alginate as an injectable delivery vehicle for bone marrow stromal cells (BMSCs). ${ }^{22}$ The endotoxicity of this naturally occurring material was drastically reduced by the developed technique of ultrapurification. $^{22}$ This ultrapurified alginate gel (UPAL gel) has favorable biological effects on in vitro chondrogenesis of BMSCs. ${ }^{22}$ Based on the concept of fixing material in the cartilage defect without periosteal coverage, a previous study showed that implantation of autologous BMSCs enhanced cartilage repair in osteochondral defects in rabbits. ${ }^{23}$ Our previous results led to a scenario in which, if host BMSCs were effectively recruited to the defects, acellular UPAL gel implantation could improve reparative tissue of osteochondral defects.

Stromal cell-derived factor-1 (SDF-1)/pre-B cell growthstimulating factor, belonging to the CXC subfamily of chemokines such as CXCL12, acts as a key chemokine of stem cell homing to bone marrow for tissue repair after injury. ${ }^{24}$

Department of Orthopaedic Surgery, Hokkaido University School of Medicine, Sapporo, Japan. 
Unlike other chemokines, SDF-1 is unique in that it binds only to its receptor, CXCR4. A recent study suggested dosedependent migration potential of human BMSCs in response to stimulation with SDF-1. ${ }^{25}$ Regarding musculoskeletal tissue repairs, we showed that an increase in local expression of SDF-1 after ligament injury of rats enhanced the homing ratio of BMSCs to the injured site. ${ }^{26}$ Kitaori et al., ${ }^{27}$ using a mouse model, showed that SDF-1 was induced in the periosteum of fractured bone and promoted endochondral bone repair by recruiting mesenchymal stem cells to the fracture site. However, to our knowledge, no studies have clarified the functional roles of SDF-1 in the reparative process of cartilaginous lesions.

We hypothesized that the combined administration of SDF-1 and UPAL gel could enhance the repair of osteochondral defects by recruiting host BMSCs to the defect site, even through acellular implantation. The final goal of this study was to determine whether the local administration of SDF-1 using UPAL gel could improve the histological findings and biomechanical properties of reparative tissues in rabbit osteochondral defects compared with those without treatment. The obtained results will be helpful in developing a technique for acellular cartilage tissue engineering, which is a safe and minimally invasive approach, with subsequent tissue regeneration by recruiting host BMSCs.

\section{Materials and Methods}

\section{Preparation of alginate gel}

An in situ forming material based on UPAL gel with a molecular weight of $1700 \mathrm{kDa}$ (Sea Matrix ${ }^{\circledR}$; Mochida Pharmaceutical Co. Ltd.) that we developed was used in this experiment. $^{22}$ This purified alginate has a quite a low endotoxin level of $5.76 \mathrm{EU} / \mathrm{g}$, compared with that of 75,950 $\mathrm{EU} / \mathrm{g}$ in commercial-grade alginate (Sodium Alginate 500, 199-09961; Wako). The current material was filter-sterilized through a $0.22 \mu \mathrm{m}$ pore-size filter and then freeze-dried for packaging in a sterilized vial. After addition of $12.5 \mathrm{~mL}$ of distilled water sterilized by filtering through a $0.45 \mu \mathrm{m}$ filter, $2 \%$ UPAL gel was used in this study.

\section{In vitro release assay of SDF-1 protein from UPAL beads}

Release studies from UPAL beads were performed in phosphate-buffered saline (PBS, pH 7.4) at $37^{\circ} \mathrm{C}$. A $40 \mu \mathrm{L}$ of UPAL bead containing $0.4 \mu \mathrm{g}$ SDF-1 was placed in a 24 -well plate with $1 \mathrm{~mL}$ of PBS per well. At each time point $(2,4,6,8$, 10,12 , and 14 days) after cultivation, the releasate was collected and stored at $-80^{\circ} \mathrm{C}$. A fresh $1 \mathrm{~mL}$ of PBS was added to the samples and they were re-incubated until the following time point. The mount of SDF-1 protein released from the samples was quantified using ELISA kits (R\&D Systems), according to the manufacturer's instructions.

\section{Expression of SDF-1 protein at the site of the osteochondral defect}

All procedures involving animals were performed under established ethical guidelines approved by the local animal care committee. Fifteen-week-old female Japanese white rabbits $(2.6-2.9 \mathrm{~kg}$ ) purchased from a professional breeder (Japan SLC) were used for creating an osteochondral defect model. Animals were anesthetized by an intravenous injection of $0.05 \mathrm{mg} / \mathrm{kg}$ pentobarbital, followed by isofluranein-oxygen gas anesthesia. After intramuscular injection of antibiotics (Penicillin G; Meiji-Seika), the bilateral lower extremities of the rabbits were shaved and draped in a sterile fashion. After a $2 \mathrm{~cm}$ anteromedial skin incision was made, the patella was everted through a small medial parapatellar approach. Using a power drill (Rexon), a full-thickness osteochondral defect $4.5 \mathrm{~mm}$ in diameter and $3 \mathrm{~mm}$ in depth was created in the patella groove of each knee. As a sham operation, we opened the knee joints without creating an osteochondral defect through the same surgical approach. At $3 \mathrm{~h}, 1$ week, 2 weeks, and 4 weeks after operation, animals were euthanized by intravenous injection of an overdose of pentobarbital. The knees were excised with a power saw. To clarify the expression of SDF-1 protein at the site of the osteochondral defect, immunohistochemical staining was carried out with a mouse anti-human/mouse SDF-1 mAb (R\&D Systems) that cross-reacted with rabbit tissues obtained at each time point. For immunohistochemical analysis, specimens were fixed with $4 \%$ phosphate-buffered paraformaldehyde, decalcified, and embedded in paraffin. A 5- $\mu$ m-thick section was obtained from the center portion of each defect. In addition, the samples were snap-frozen for Western blotting. The frozen samples were crushed with a hammer, then homogenized in $8 \mathrm{M}$ urea, $50 \mathrm{mM}$ phosphate, $10 \mathrm{mM}$ Tris ( $\mathrm{pH} 8.0$ ) buffer using a motorized homogenizer. EDTA $(50 \mathrm{mM})$ was added to an aliquot of the homogenate. After 24-h incubation at room temperature, the homogenate was centrifuged to obtain the supernatant. Levels of SDF-1 protein were then assessed by Western blotting using a mouse anti-human SDF-1 mAb (1:250, R\&D Systems).

\section{In vivo cell homing assessment}

To quantitatively evaluate cell homing or migration into the defect site after local administration of SDF-1, the number of cells that migrated into the implanted site of UPAL gel was counted at 7 days postoperatively. The implanted gels were removed using a sharp curette and the obtained specimens were fixed with $4 \%$ phosphate-buffered paraformaldehyde for $24 \mathrm{~h}$, embedded in paraffin, cut into 5 - $\mu \mathrm{m}$-thick sections from the center of the gel, and stained with hematoxylin and eosin (H-E) using standard histochemical techniques. The experimental groups, including the vehicle, SDF-1, and AMD3100 groups, are described below.

\section{Rabbit cartilage repair model}

The osteochondral defects created by the above procedure were dried and filled with $2 \%$ UPAL gel containing each protein. The gel did not flow out of the defect site because of its high viscosity. Without any additional coverage or fixation to the implantation site, the capsule and skin were closed with 4-0 black nylon sutures. The rabbits were allowed to freely move in their cages. A previous study demonstrated that the implanted UPAL gel remained at the surface of similar rabbit osteochondral defects to the current ones while maintaining the initial shape at 2 weeks postoperatively. ${ }^{22}$ The articular cartilage defects were divided into four treatment groups ( $n=10$ in each group) as follows: defect, no treatment; vehicle, UPAL gel containing $10 \mu \mathrm{g} / \mathrm{mL}$ bovine serum albumin; SDF-1, UPAL gel containing $10 \mu \mathrm{g} /$ 
mL SDF-1 (Miltenyi Biotec, Inc.); and AMD3100, UPAL gel containing $250 \mu \mathrm{g} / \mathrm{mL}$ AMD3100, an antagonist of CXCR4 (Sigma-Aldrich). The concentrations of SDF-1 and AMD3100 were determined by our preliminary study (data not shown).

\section{Macroscopic, histological and immunohistochemical evaluations}

At 4 and 16 weeks after operation, animals were euthanized for further investigations. The knee samples were obtained by the method described above and photographed with a digital camera for macroscopic evaluation. The specimens were prepared for histological and immunohistochemical analyses as described above. A 5- $\mu$ m-thick section was obtained from the center portion of each defect. The sections were stained with safranin-O and H-E. To quantitatively evaluate the reparative tissue in each group, macroscopic and histological findings were scored with the 8-point and 28-point grading scales of Niederauer et al., ${ }^{23}$ a modification of the scoring system reported by $\mathrm{O}^{\prime}$ Driscoll. ${ }^{28}$ The scores were determined by an independent blinded observer. Immunohistochemical staining was performed with anti-type I and anti-type II collagen antibodies (Fuji Pharm. Lab.). For quantitative evaluation of glycosaminoglycan (GAG) content and type II collagen content, the findings of safranin-O and type II collagen staining were scored using the 3-point grading scales of Mohan's scoring system. ${ }^{29}$ To ensure an adverse effect of SDF-1 administration, immunohistochemical staining was performed with matrix metalloproteinase (MMP)-13 antibody (Abcam).

\section{Biomechanical analysis of in vivo samples}

Biomechanical testing was performed on the samples obtained from the euthanized rabbits and four slices of normal rabbit cartilage as a control. At 4 and 16 weeks after operation, the mechanical properties of the samples obtained from each group were measured using the axial compression test equipment designed by our laboratory for small samples. ${ }^{22,30,31}$ A rod with a hemispherical tip $(2.5 \mathrm{~mm}$ in diameter) was vertically pressed at a crosshead speed of $10 \mathrm{~mm} / \mathrm{min}$ on the sample placed on a grid. The compression modulus was obtained from the initial slopes of the stress-strain curves.

\section{Preparation of BMSCs}

BMSCs were isolated from 15-week-old Japanese white rabbits. Bone marrow was obtained from the femurs and tibias by flushing the shaft using a syringe with a No. 18-gauge needle under sterile conditions. BMSCs were isolated according to the procedure reported by Wakitani et al. ${ }^{32}$ The cells at second passage were used for further experiments. In a $37^{\circ} \mathrm{C}$, humidified $5 \% \mathrm{CO}_{2}$ incubator, the isolated cells were maintained in monolayer culture.

\section{Alginate encapsulation and recovery of cells}

Cells were suspended in the UPAL-gel at the desired concentration and dropped from a pipette into $\mathrm{CaCl}_{2}$ solution (Wako). The UPAL-gel-BMSC suspension gelled completely at $10 \mathrm{~min}$ after contact with the $\mathrm{CaCl}_{2}$ solution. For the recovery of cells from the alginate gel, alginate beads were secured, washed three times with PBS, and then placed in $50 \mathrm{mM}$ EDTA (Gibco BRL Laboratories) in a $37^{\circ} \mathrm{C}, 5 \% \mathrm{CO}_{2}$ incubator. Ten minutes later, cells were recovered by centrifugation at $1500 \mathrm{~g}$ for $5 \mathrm{~min}$.

\section{In vitro cell viability assay}

To investigate the effects of SDF-1 AMD3100 on cellular viability, BMSCs embedded in UPAL gel beads were cultured in DMEM-HG supplemented with 10\% FBS and 1\% antibiotics. At $0,1,2,3$, and 7 days after encapsulation, cultured beads were dissolved as described above. The number of viable cells at each time was counted with Cell Counting Kit-8 (Dojindo Laboratories). For further investigations, the concentrations of SDF-1 and AMD3100 in the beads were $10 \mu \mathrm{g} / \mathrm{mL}$ and $250 \mu \mathrm{g} / \mu \mathrm{L}$, respectively. UPAL gel alone was used as a control.

\section{In vitro cell migration assay}

We assessed the influence of SDF-1 on cell migration of BMSCs using the CytoSelect ${ }^{\mathrm{TM}}$ 96-well cell migration assay $(8 \mu \mathrm{m}$, Fluorometric Format; Cell Biolabs) following the manufacturer's instructions. ${ }^{33-35}$ Briefly, feeder tray wells were filled with $150 \mu \mathrm{L}$ of medium with or without SDF-1. Confluent cells were harvested and $100-\mu \mathrm{L}$ aliquots of serumfree medium containing $5 \times 10^{5}$ cells $/ \mathrm{mL}$ were added to the wells of the membrane tray (upper tray). Migration assays were run for $8 \mathrm{~h}$ at $37^{\circ} \mathrm{C}$ in a $5 \% \mathrm{CO}_{2}$ incubator, after which the medium was removed from the membrane tray and the tray was placed over a harvesting tray containing $150 \mu \mathrm{L}$ of the cell detachment solution for $30 \mathrm{~min}$ at $37^{\circ} \mathrm{C}$. The cells were treated with fluorescent dye and measured at 480/ $520 \mathrm{~nm}$ using a SpectraMax M2 Plate Reader (Molecular Devices).

\section{In vitro chondrogenic differentiation of BMSCs in UPAL gel}

Forty microliters of UPAL gel beads containing $1 \times 10^{6}$ BMSCs was placed into each well of 24-well culture dishes. The beads were then cultured in $1 \mathrm{~mL}$ of complete chondrogenic medium consisting of DMEM-HG supplemented with $100 \mu \mathrm{g} / \mathrm{mL}$ sodium pyruvate (ICN Biomedicals), $40 \mu \mathrm{g}$ / $\mathrm{mL}$ proline (ICN Biomedicals), $50 \mu \mathrm{g} / \mathrm{mL}$ ascorbic acid-2phosphate (Wako), $1 \times 10^{-7} \mathrm{M}$ dexamethasone (ICN Biomedicals), 1\% ITS plus mix (Sigma-Aldrich), 1\% antibiotics, and $10 \mathrm{ng} / \mathrm{mL}$ recombinant human transforming growth factor ๙3 (R\&D Systems), dissolved in $4 \mathrm{mM} \mathrm{HCl}$ containing $1 \mathrm{mg} /$ $\mathrm{mL}$ bovine serum albumin. The plates were maintained at $37^{\circ} \mathrm{C}$ in an incubator with the medium changed every 3 days. At 28 days after cultivation, each bead was washed with PBS and fixed with $4 \%$ phosphate-buffered paraformaldehyde for $24 \mathrm{~h}$ and embedded in paraffin. Then a $5-\mu \mathrm{m}$-thick section was cut from the center of the bead. This section was stained with $\mathrm{H}-\mathrm{E}$, and safranin-O using standard histochemical techniques. Immunohistochemical staining was performed with anti-type I and anti-type II collagen antibodies.

\section{Data analysis}

All data are presented as mean \pm standard error. Significant differences among three or more groups were assessed by one-way ANOVA followed by multiple-comparison post hoc tests. Comparisons between two groups were performed 
by unpaired $t$-tests. Statistical analyses were performed using GraphPad Prism (Version 5.00; GraphPad Software, Inc.). $p$-Values of less than 0.05 were considered statistically significant. To avoid observer bias, slides were coded before analysis.

\section{Results}

\section{Release of SDF-1 protein from the UPAL bead}

The release of SDF-1 protein from the UPAL bead to the culture medium was found from 2 to 14 days after cultivation (Fig. 1).

\section{Expression of SDF-1 protein after osteochondral injury}

Immunohistochemical analysis revealed cells expressing SDF-1 protein in the injury site at 1 week after creation of the osteochondral defect (Fig. 2B, J), whereas the expression was not found at $3 \mathrm{~h}, 2$ weeks, or 4 weeks after injury (Fig. 2A, C, D). After sham operation, no local expression of SDF-1 protein was observed at any time point (Fig. 2E-H). Western blot analysis showed enhanced expression of SDF-1 protein only in the tissue obtained at 1 week after injury, confirming the results of immunohistochemical analysis (Fig. 2Q).

\section{In vivo migratory effects of SDF-1 on host cells}

At 1 week postoperatively, histological findings of the SDF-1 group showed more host cells in the rabbits with UPAL gel implanted into the osteochondral defect than in the other groups (Fig. 3A-F). The quantitative analysis demonstrated that the cell number was significantly higher in the SDF-1 group than in the other groups $(n=5$ in each group; $p<0.01$ vs. the vehicle group; $p<0.001$ vs. the AMD3100 group, Fig. 3G). Although the cell number of the vehicle group tended to increase compared with that of the AMD3100 group, there was no significant difference between the two groups. These results suggested that local

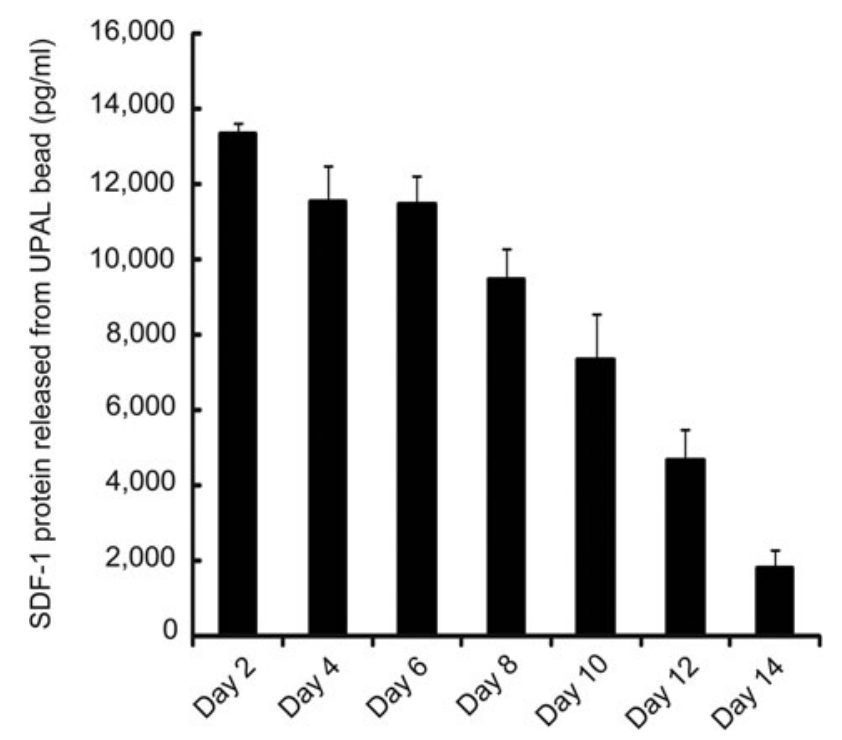

FIG. 1. In vitro release kinetics of stromal cell-derived factor-1 (SDF-1) protein from the ultrapurified alginate (UPAL) bead. administration of SDF-1 enhanced the migration of host cells to the site of the osteochondral defect.

\section{Macroscopic morphology}

No macroscopic signs indicating infection such as pyogenic fluid or purulent synovitis were found in any knees at any time point. The implanted UPAL gel remained in the osteochondral defects of the patellar groove in the vehicle and AMD3100 groups at 4 weeks postoperatively (Fig. 4B, D). In the defect and AMD3100 groups, the surface of the reparative tissue was somewhat rough, slightly depressed, and poorly integrated with the adjacent cartilage even at 16 weeks postoperatively (Fig. 4A, D, E, H). On the other hand, the smoothness of the surface and the integration with the adjacent cartilage at 16 weeks postoperatively were improved in the vehicle and SDF-1 groups (Fig. 4F, G). The defects in the SDF-1 group at 4 weeks postoperatively were partially filled with firm, glossy white material (Fig. 4C). At 16 weeks postoperatively, the defects were entirely replaced with such cartilage-like tissue (Fig. 4G).

Mean total macroscopic scores significantly improved from 4 to 16 weeks postoperatively in all groups $(n=10$ in each group at each time point; $p<0.01$ in the defect, vehicle, and SDF-1 groups; $p<0.001$ in the AMD3100 group; Fig. 4I, J). Regarding the comparisons among the groups, the total macroscopic scores at 4 weeks postoperatively were significantly higher in the SDF-1 group than in the other groups $(p<0.001$ vs. the defect and AMD3100 groups, $p<0.01$ vs. the vehicle group; Fig. 4I). The scores in the AMD3100 group significantly decreased compared with those in the vehicle group $(p<0.05$, Fig. 4I). The scores in the SDF-1 group at 16 weeks were also significantly higher than in the other groups $(p<0.01$ vs. the defect group, $p<0.05$ vs. the vehicle and AMD3100 groups; Fig. 4J). No other significant differences in the scores were found among the groups.

\section{Histological and immunohistochemical findings}

At 4 weeks after operation. The reparative tissue in the defect and AMD3100 groups was replaced with fibrillated fibrous tissues mainly containing type I collagen (Fig. 5A, D, E, H, I, L). On the other hand, the defect sites in the vehicle and SDF-1 groups were partially repaired with hyaline-like cartilaginous tissue containing GAG matrix and type II collagen (Fig. 5B, C, J, K). The reparative tissue in both groups partially included type I collagen (Fig. 5F, G). In the vehicle group, fissures were observed in the defect site (Fig. 5B). No reconstruction of normal subchondral bone structure, a smooth cartilage surface, or a complete tidemark was found in any group (Fig. 5A-D).

Mean total histological scores in the SDF-1 group were significantly higher than those in the other groups $(n=5$ in each group, $p<0.01$ vs. the defect and AMD3100 groups, $p<0.05$ vs. the vehicle group; Fig. 5M). No significant differences in the values were found among the other three groups. The scores for GAG content were significantly higher in the SDF-1 group than in the defect and AMD3100 groups ( $n=5$ in each group, $p<0.001$; Fig. $5 \mathrm{~N}$ ). The values for type II collagen content in the SDF-1 group significantly increased, compared with those in the defect group ( $n=5$ in each group, $p<0.01$; Fig. 5O). 


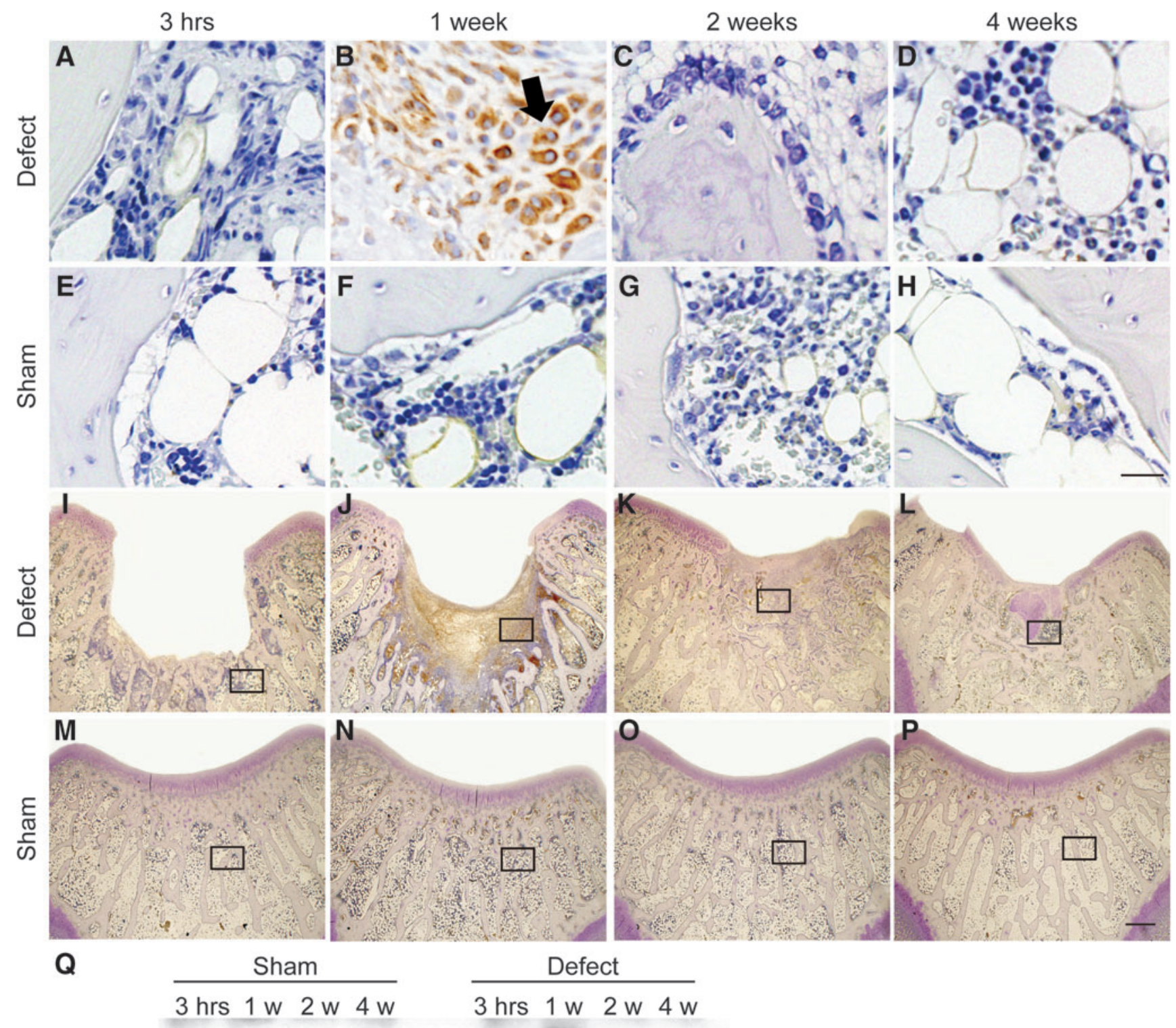

SDF-1

GAPDH
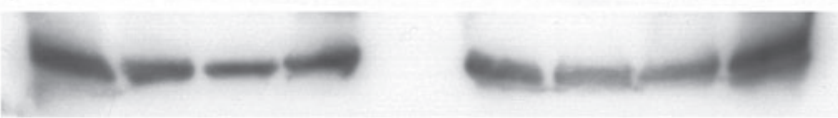

FIG. 2. SDF-1 protein expression in rabbit knee. (A-D) Immunohistochemistry of osteochondral defect for SDF-1 at each time point after operation. The black arrow indicates cells expressing SDF-1 protein (B). (E-H) Immunohistochemistry of intact articular surface for SDF-1 at each time point after sham operation. Scale bar: $50 \mu \mathrm{m}$. (I-L) Low magnification of the osteochondral defect for SDF-1 at each time point after operation. (M-P) Low magnification of the intact articular surface for SDF-1 at each time point after sham operation. Each box indicates high magnification area shown in (A-D). Scale bar: $1.5 \mathrm{~mm}$. (Q) Western blot analysis. The analysis at 1 week after surgery shows enhanced expression of SDF-1 protein in the sample of the osteochondral defect. GAPDH, glyceraldehyde 3-phosphate dehydrogenase.

The reparative tissue in the defect demonstrated strong MMP-13 staining (Fig. 7A). On the other hand, the defect sites in the SDF-1 group showed no apparent MMP-13 staining (Fig. 7B).

At 16 weeks after operation. The defect group showed repair with only fibrous tissues and had some fissures and severely disrupted surfaces (Fig. 6A, E, I). The AMD3100 and vehicle groups demonstrated hypocellular fibrocartilagious repair with weak type I and type II collagen staining (Fig. 6B, D, F, H, J, L). The vehicle clearly enhanced the repair of subchondral bone in the defects (Fig. 6B) compared with the defect and AMD3100 groups (Fig. 6A, D). Fissures were observed at the border between the defect and adjacent cartilage in the AMD3100 group (Fig. 6D), whereas no such findings were observed in the vehicle group (Fig. 6B). On the other hand, the SDF-1 group exhibited nearly normal cartilaginous structures with rich GAG matrix content and strong type II collagen 

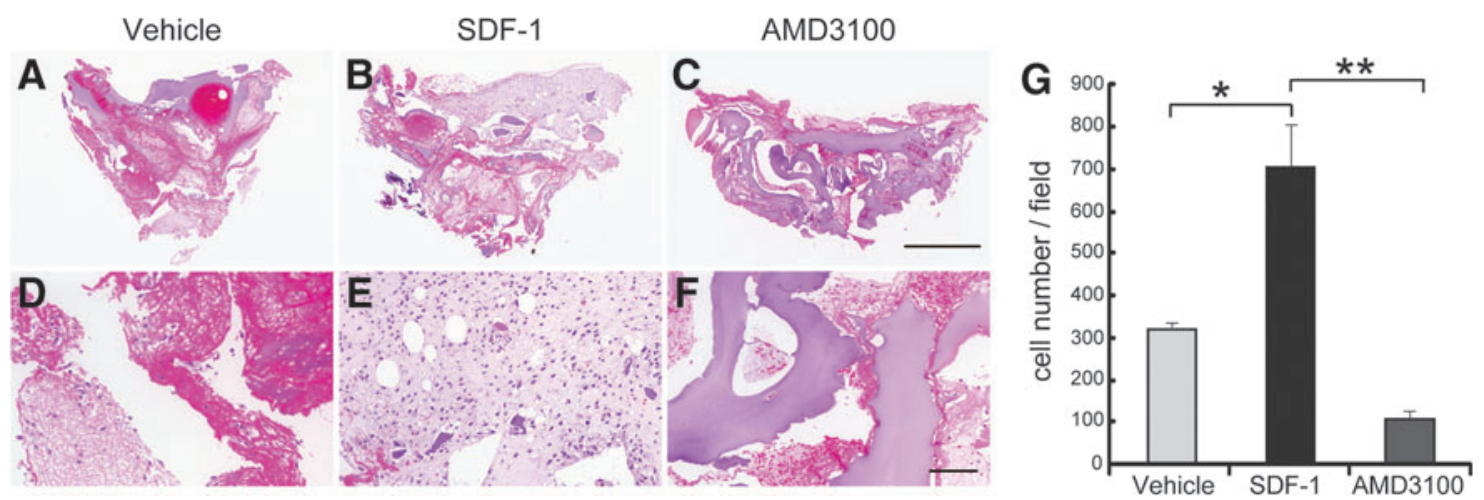

FIG. 3. In vivo cell homing assay of the UPAL gel implanted into the osteochondral defect. (A-F) Histological sections at 1 week postoperatively. (A-C) Low magnification. Scale bar: $1 \mathrm{~mm}$. (D-F) High magnification. Scale bar: $100 \mu \mathrm{m}$. (A, D) Vehicle group, (B, E) SDF-1 group, (C, F) AMD3100 group. (G) Cell numbers per field in five randomly chosen fields (A) $(n=5)$. Values are mean and SEM. ${ }^{*} p<0.01,{ }^{* *} p<0.001$.

staining, reconstruction of the normal subchondral bone structure, a smooth cartilage surface, and a tidemark (Fig. 6C, $\mathrm{K})$. Type I collagen staining was not found in the cartilaginous layer (Fig. 6G). The neocartilaginous reparative tissue was integrated into the adjacent cartilage and bone (Fig. 6C).

The total histological scores in the vehicle and SDF-1 groups significantly improved from 4 to 16 weeks postoperatively $(p<0.05$ in the vehicle group, $p<0.01$ in the SDF-1 group; Figs. $5 \mathrm{M}$ and $6 \mathrm{M}$ ). The scores at 16 weeks after operation were significantly higher in the SDF-1 group than in the other groups ( $n=5$ in each group, $p<0.001$; Fig. $6 \mathrm{M})$. The values in the vehicle group were significantly superior to those in the defect group ( $p<0.01$, Fig. 6M). No significant differences in the scores were found between the defect group and AMD3100 group. The SDF-1 group significantly increased the scores for GAG content compared with those of other groups $(n=5$ in each group, $p<0.001$; Fig. $6 \mathrm{~N})$. The values for type II collagen content were significantly higher in the SDF-1 group than in other groups $(n=5$ in each group, $p<0.001$ in the defect and AMD3100 groups, $p<0.01$ in the vehicle group; Fig. 6O).

The MMP-13 staining in the SDF-1 group appeared to be reduced, compared with that in the defect group (Fig. 7B, D).

\section{Measurement of mechanical properties}

At 4 weeks postoperatively, the compressive modulus in all groups was significantly lower than that of normal cartilage $(n=5$ in each group, $p<0.001$, Table 1$)$. There were no
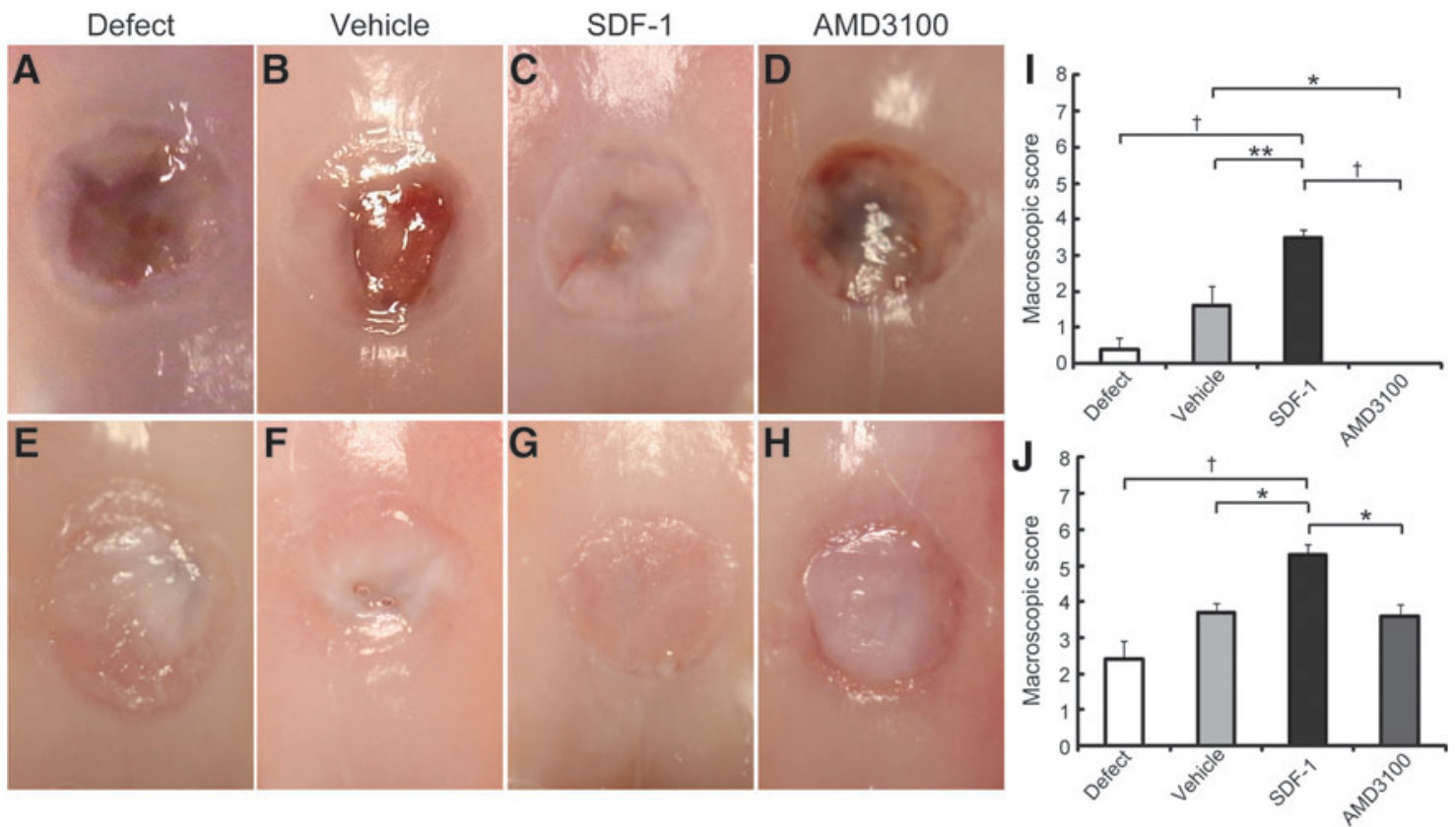

FIG. 4. Macroscopic morphology of osteochondral defects at 4 weeks (A-D) and at 16 weeks (E-H) postoperatively. Macroscopic scores at 4 weeks (I) and at 16 weeks (J) postoperatively ( $n=10$ at each time point). Niederauer's macroscopic scoring scale range: $0-8$. Values are mean and SEM. ${ }^{*} p<0.05,{ }^{* *} p<0.01,{ }^{\dagger} p<0.001$. 
FIG. 5. Histological sections of osteochodral defects at 4 weeks after operation. The sections were stained with safranin-O (A-D), and immunohistochemically stained with anti-type I (E-H) and anti-type II (I-L) collagen antibodies. Scale bar: $1 \mathrm{~mm}$. (M) Histological scores at 4 weeks postoperatively $(n=5)$. Niederauer's histological scoring scale range: $0-$ 28. Histological scores for glycosaminoglycan (GAG) content $(\mathbf{N})$ and type II collagen content $(\mathbf{O})$ at 4 weeks postoperatively $(n=5)$. Scoring scale range: $0-3$. Values are mean and SEM. ${ }^{*} p<0.01,{ }^{* *} p<0.001$.
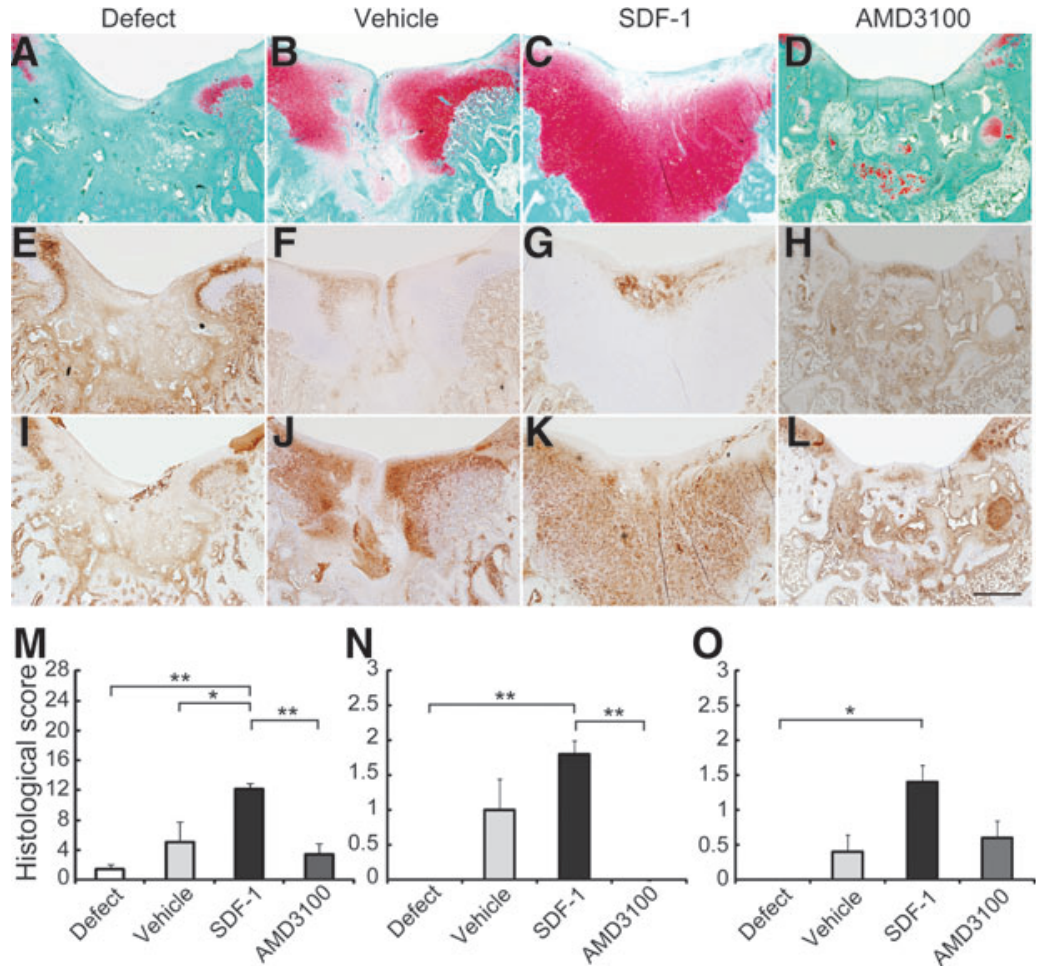

significant differences in the value among the experimental groups. From 4 to 16 weeks, the moduli of all groups except the defect group significantly improved $(p<0.001$ in the SDF-1 group, $p<0.01$ in the vehicle and AMD3100 groups; Table 1). At 16 weeks postoperatively, the values in the vehicle and AMD3100 groups were significantly superior to that in the defect group ( $n=5$ in each group, $p<0.01$; Table 1$)$. In the SDF-1 group the modulus was significantly improved compared with the defect group $(p<0.001$, Table 1$)$ and reached $\sim 81 \%$ of that of normal cartilage. Only the modulus in the SDF-1 group showed no significant difference compared with normal cartilage.
FIG. 6. Histological sections of osteochodral defects at 16 weeks after operation. The sections were stained with safranin-O (A-D), and immunohistochemically stained with antitype I (E-H) and anti-type II collagen antibodies (I-L). Scale bar: $1 \mathrm{~mm}$. (M) Histological scores at 16 weeks postoperatively $(n=5)$. Niederauer's histological scoring scale range: 0-28. Histological scores for GAG content (N) and type II collagen content $(\mathrm{O})$ at 16 weeks postoperatively $(n=5)$. Scoring scale range: 0 3. Values are mean and SEM. ${ }^{*} p<0.01$, ** $p<0.001$.

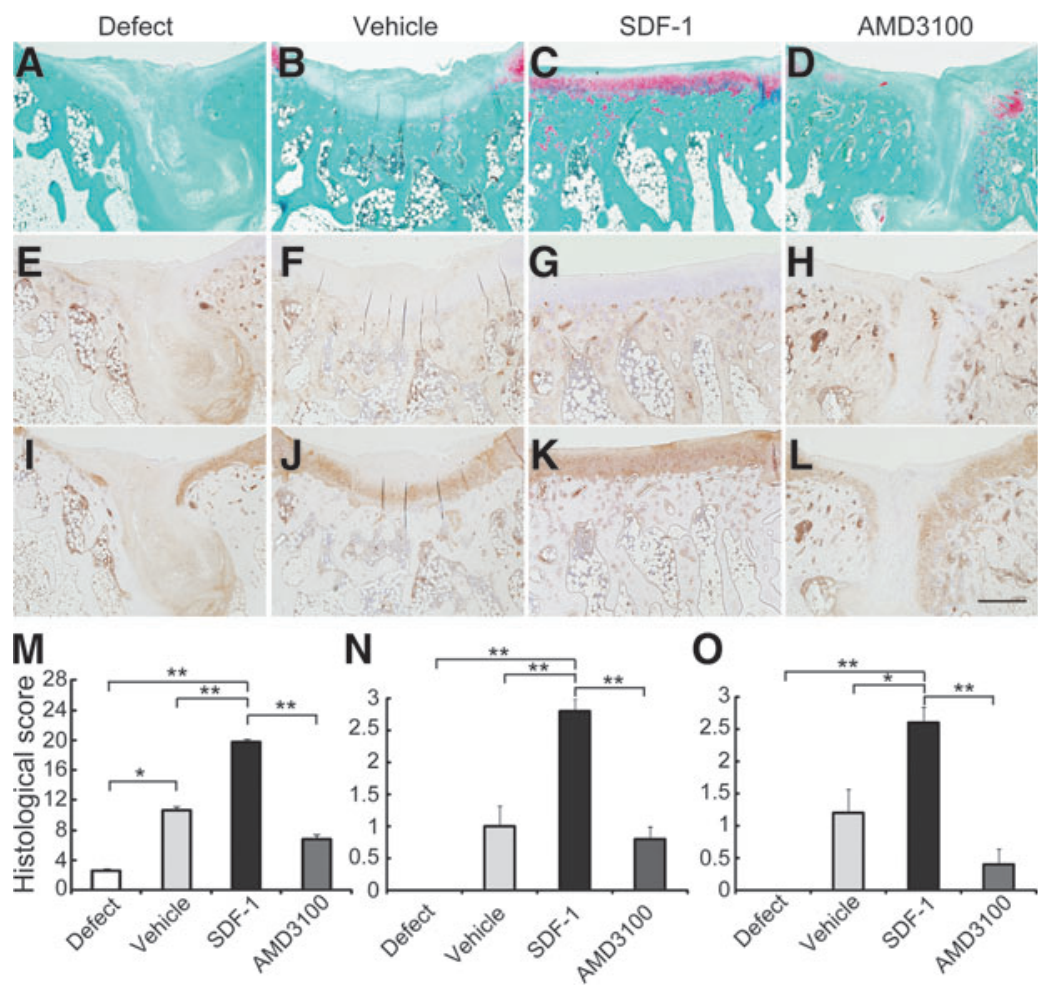




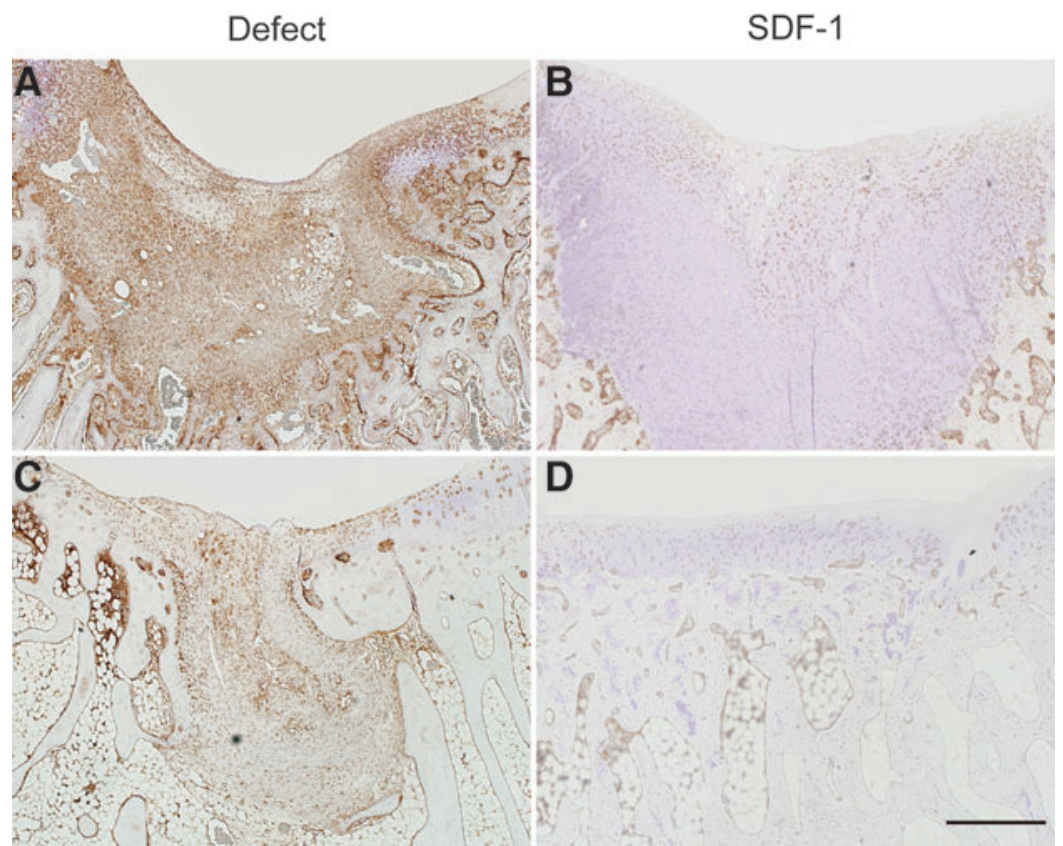

FIG. 7. Local expression of MMP-13 protein in osteochondral defects at 4 and 16 weeks after operation. (A, B) At 4 weeks postoperatively in the defect and SDF-1 groups. (C, D) At 16 weeks postoperatively in the defect and SDF-1 groups. Scale bar: $1 \mathrm{~mm}$.

In vitro effects of SDF-1 on BMSC behaviors

In the SDF-1 group in vitro BMSC migration significantly increased compared with the control group $(n=16$ in each group, $p<0.01$; Fig. 8A). The cell proliferation assay showed no significant difference at any time point among the ex- perimental groups ( $n=5$ in each group at each time point, Fig. 8B). Histological and immunohistochemical analyses demonstrated no apparent differences in chondrogenesis of BMSCs in UPAL gel beads among the groups (Fig. 8C-H). These results indicated that SDF-1 had no direct effects on cellular proliferation and chondrogenesis of BMSCs.
A

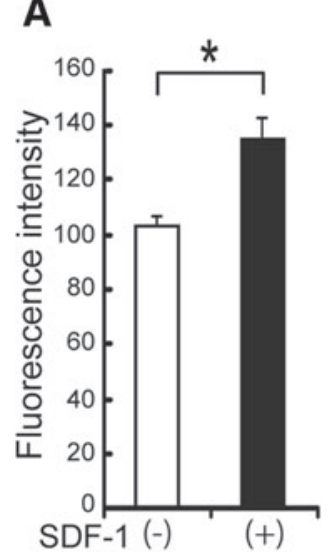

B
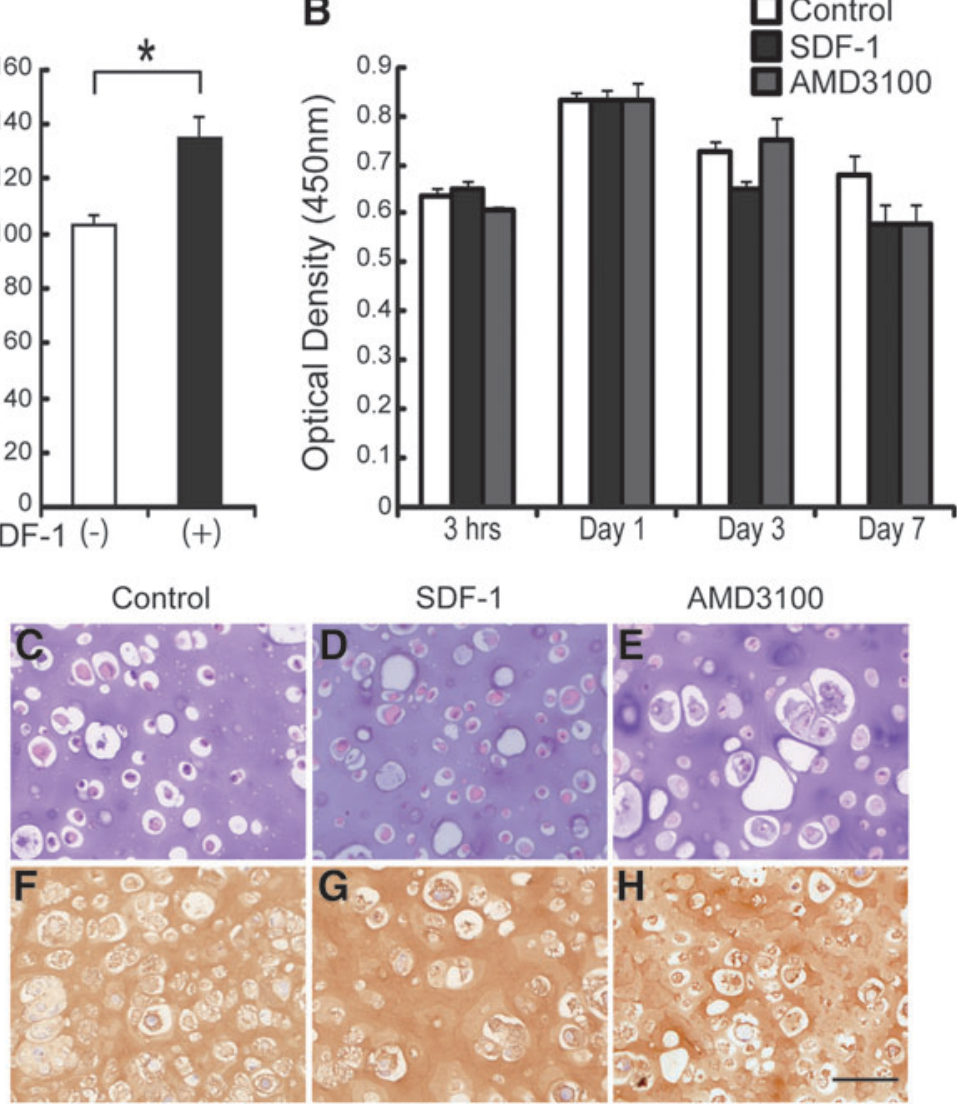

FIG. 8. In vitro effects of SDF-1 on bone marrow stromal cell (BMSC) behaviors. (A) Cell migration assay by CytoSelect with and without addition of SDF-1 to culture medium $(n=16)$. (B) Cell proliferation assay by WST-8 $(n=5$ at each time point). Values are mean and SEM. ${ }^{*} p<0.001$. (C-H) In vitro histological and immunohistochemical appearances of UPAL gel with BMSCs at 28 days after cultivation.

Alginate beads stained with H-E (C-E) and immunohistochemically stained with the anti-type II collagen antibody (F-H). Scale bar: $100 \mu \mathrm{m}$. 


\section{Discussion}

Our aim was to determine whether the local administration of SDF-1 using UPAL gel could enhance repair of osteochondral defects in rabbits. The results showed that the SDF-1 treatment (UPAL gel containing SDF-1) significantly improved the histological scores and compressive modulus of reparative tissues compared to other experimental groups, including the vehicle (UPAL gel without SDF-1) group. Regarding an adverse effect of SDF-1 administration, immunohistochemical findings suggested that SDF-1 did not stimulate the expression of MMP-13 in reparative tissues. Therefore, we reasonably concluded that the injection of SDF-1 embedded in the UPAL gel histologically and biomechanically enhanced the reparative process of osteochondral defects.

The assessment of extracellular matrix content, including type II and GAG, in reparative tissues is important to determine the repair with hyaline-like cartilage after the treatment of osteochondral defects. Real-time PCR analyses by Kim et $a l .{ }^{36}$ showed the upregulated expressions of Type II collagen and aggrecan in rabbit reparative tissues at 8 and 16 weeks after chondrocyte implantation delivered by a heparine-based hydrogel. On the other hand, Hoeman et al. ${ }^{37}$ showed that sheep repair tissue at 24 weeks after acellular treatment using chitosan-glycerol phosphate/blood implantation contained nearly twofold more GAG and collagen compared with that from control defects treated with microfracture alone. In our study, the SDF-1 group significantly increased the scores for GAG and type II collagen contents compared with the control defect group at 4 and 16 weeks postoperatively. The studies by Hoeman et al. ${ }^{37}$ and the authors demonstrate a potential of hyaline-like tissue repair for cartilaginous lesions by acellular treatment strategies.

The authors, ${ }^{26}$ using a rat model, demonstrated that the local expression of SDF-1 was temporarily upregulated, peaking at 2 weeks after medial collateral ligament injury. Kitaori et al. ${ }^{27}$ detected high expression of SDF-1 protein in the periosteum of the graft bone on day 2 during the healing of bone grafts in mice. Misao et al. ${ }^{38}$ showed upregulation of SDF-1 expression in rabbit myocardial tissues at 7 days after the occurrence of myocardial infarction. On the other hand, Shen et al..$^{39}$ reported that the expression of SDF-1 was upregulated until 4 months after a stroke. Regarding the timing of SDF-1 upregulation, the inconsistencies among these tissues and organs may be attributable to differences in cellu-

Table 1. Compressive Modulus in Experimental Groups

\begin{tabular}{lcc}
\hline Group & 4 weeks $(\mathrm{MPa})$ & 16 weeks $(\mathrm{MPa})$ \\
\hline Defect & $0.66 \pm 0.08^{\mathrm{a}}$ & $0.59 \pm 0.11^{\mathrm{a}}$ \\
Vehicle & $0.50 \pm 0.16^{\mathrm{a}}$ & $1.82 \pm 0.28^{\mathrm{b}, \mathrm{d}}$ \\
SDF-1 & $0.89 \pm 0.05^{\mathrm{a}}$ & $2.34 \pm 0.38^{\mathrm{c}}$ \\
AMD3100 & $0.60 \pm 0.93^{\mathrm{a}}$ & $1.89 \pm 0.18^{\mathrm{b}, \mathrm{d}}$ \\
Normal cartilage & & $2.89 \pm 0.25$ \\
\hline
\end{tabular}

Mean \pm SEM.

${ }^{a} p<0.001$ vs. normal knee.

${ }^{\mathrm{b}} p<0.01$ vs. defect at the same time.

${ }^{c} p<0.001$ vs. defect at the same time.

$\mathrm{d} p<0.05$ vs. normal knee.

SDF-1, stromal cell-derived factor-1. larity. Cellular and tissue responses to acute cartilage injury are generally classified into three phases as follows: (1) the early phase is characterized by cell death/apoptosis and inflammation (0-6 days after injury); (2) the intermediate phase follows, when a potential balance between catabolic and anabolic responses may exist (6-8 days after injury); and (3) the late phase with repair/remodeling/matrix formation (8-14 days after injury). ${ }^{40}$ The current study showed that the transient expression of SDF-1 protein around the injury site occurred at 1 week after surgery. In addition, the local administration of AMD3100, an antagonist of CXCR4, impaired the repair of osteochondral defects. Taken together, these results indicated that SDF-1 played a crucial role in repairing osteochondral defects during the intermediate phase of the reparative process, when anabolic responses are initiated.

The injury created here involves disruption of the articular cartilage with penetration into the subchondral bone. The reparative process of this injury includes formation of a fibrin clot and recruitment of undifferentiated mesenchymal cells into the clot. Then the recruited cells produce reparative tissue that mainly consists of fibrocartilaginous tissue, not hyaline cartilage. To achieve hyaline-like cartilage repair, a reasonable approach is to enhance cellular and/or tissue activities in each reparative phase. Regarding the recruitment of host cells, in the SDF-1 treatment group the number of cells that migrated into the defect site significantly increased at 1 week postoperatively compared with other treatment groups. Our in vitro cell migration assay also showed that SDF-1 significantly increased the migration of BMSCs, supporting the in vivo findings. These results indicated that the chemotactic effect of SDF-1 enhanced the migration of host cells, mainly including BMSCs, to osteochondral defects.

Our previous study demonstrated that UPAL gels clearly enhanced in vitro chondrogenesis of BMSCs. ${ }^{22}$ In the current study, the UPAL gel containing SDF-1 beads did not notably improve the proliferation and chondrogenesis of BMSCs in UPAL gel-alone beads. This suggested that there was no direct effect of SDF-1 on chondrogenesis of BMSCs. The authors showed that SDF-1 had no direct effects on cellular behavior of BMSCs in terms of the proliferation, adhesivity, and differentiation to ligament fibroblasts. ${ }^{26}$ Jung et al. ${ }^{41}$ also reported that SDF-1 had no significant effect on the proliferation of fibroblasts. These previous studies support the current results. Collectively, the results obtained here indicated that SDF-1 influenced the reparative process of osteochondral injuries not through direct effects on the behaviors of host cells, mainly BMSCs, but by increasing their homing rate to the injury site. Regarding cellular differentiation, the implanted UPAL gel may play a crucial role in the chondrogenesis of the recruited host cells. We speculate that these biological effects of both SDF-1 and UPAL gel on the tissue reparative process enhance cartilage tissue repair in the living joint.

Tissue engineering fundamentally combines isolated cells with scaffolds to regenerate damaged tissues. The primary advantage of cartilage tissue engineering and ACI is the development of hyaline-like cartilage rather than fibrocartilage in osteochondral defects. This presumably leads to better long-term clinical outcomes. However, the standard procedure currently performed has considerable limitations. It requires at least two operations, one for tissue harvesting 
to isolate chondrocytes and the other for chondrocyte implantation. Further, the standard procedure is performed through a wide arthrotomy and has risks of complications related to the periosteal graft such as periosteal hypertrophy, ${ }^{6,19}$ falling off of the graft site, ${ }^{42}$ or intra-articular adhesion. Cell-free approaches like the implantation of naturally occurring or synthetic scaffolds into the defects are based on complementing basic biological repair strategies such as marrow-stimulation techniques and ACI. The procedures can minimize complications by avoiding the harvesting and implantation of cells and of periosteum, and prevent dedifferentiation of isolated chondrocytes during cultivation. In addition, the cell-free approaches make an arthroscopic implantation technique feasible for accessible lesions. A multicenter study of the clinical outcomes after ACI demonstrated that $26 \%$ of the procedure-related complications were associated with the open arthrotomy. ${ }^{6}$ Cell-free approaches can combine the ability to improve clinical outcomes of cartilage tissue engineering and efficacy in a cost-effective manner by minimizing the adverse effects of the procedures currently performed.

There have been two main cell-free approaches for cartilage tissue engineering. One is to develop a threedimensional scaffold for implantation, ${ }^{43-45}$ and the other is to locally apply growth factors, cytokines, or a combination of these proteins. ${ }^{46-48}$ However, the former strategy has a limitation in the number of cells recruited to the injury site, and with the latter one, a loss of protein activity tends to occur immediately after implantation. These considerations prompted us to develop a novel acellular approach. Our previous study ${ }^{22}$ demonstrated that the UPAL gel was completely reabsorbed between 2 and 4 weeks after implantation in living joints. Rabbany et al. ${ }^{49}$ reported that alginate patches prolonged the in vivo retention of SDF-1 protein over 2 weeks after surgery. Because heparin and spermine introduced into the alginate material can bind to SDF-1, this protein binds to the material and consequently achieves prolonged in vivo retention in a biologically active form. Our in vitro assessment regarding release kinetics of SDF-1 protein from UPAL gel supports their results.

There are further considerations for the clinical application of our results. First, our evaluation of this treatment strategy was based on the results derived from a rabbit model. Second, in vivo analyses were performed using samples at 4 and 16 weeks postoperatively. Long-term assessments using a large animal model need to be performed to adapt our approach for use in humans.

In conclusion, we succeeded in achieving hyaline-like cartilage repair by local administration of SDF-1 using UPAL gel without cells. The obtained results indicate that UPAL gel enhances chondrogenesis of BMSCs recruited by the chemotactic effect of SDF-1, leading to a novel cell-free approach for cartilage tissue engineering.

\section{Acknowledgments}

This study was supported by a Grant-in-Aid for Scientific Research from Japan Society for the Promotion of Science (B-22390285), and "Development of a Novel Injectable Material for the Treatment of Joint Disorders" Science and Technology Incubation Program in Advanced Regions, Japan Science and Technology Agency.

\section{Disclosure Statement}

No competing financial interest exists.

\section{References}

1. Pridie, K.H. A method of resurfacing osteoarthritic knee joints. J Bone Joint Surg Br 41, 618, 1959.

2. Steadman, J.R., Rodkey, W.G., and Rodrigo, J.J. Microfracture: surgical technique and rehabilitation to treat chondral defects. Clin Orthop Relat Res 391 Suppl, S362, 2001.

3. Johnson, L.L. Arthroscopic abrasion arthroplasty historical and pathologic perspective: present status. Arthroscopy 2, $54,1986$.

4. O'Driscoll, S.W., Keeley, F.W., and Salter, R.B. Durability of regenerated articular cartilage produced by free autogenous periosteal grafts in major full-thickness defects in joint surfaces under the influence of continuous passive motion. A follow-up report at one year. J Bone Joint Surg Am 70, 595, 1988.

5. Brittberg, M., Lindahl, A., Nilsson, A., Ohlsson, C., Isaksson, O., and Peterson, L. Treatment of deep cartilage defects in the knee with autologous chondrocyte transplantation. N Engl J Med 331, 889, 1994.

6. Peterson, L., Minas, T., Brittberg, M., Nilsson, A., SjogrenJansson, E., and Lindahl, A. Two- to 9-year outcome after autologous chondrocyte transplantation of the knee. Clin Orthop Relat Res 374, 212, 2000.

7. Brittberg, M., Peterson, L., Sjogren-Jansson, E., Tallheden, T., and Lindahl, A. Articular cartilage engineering with autologous chondrocyte transplantation. A review of recent developments. J Bone Joint Surg Am 85 Suppl 3, 109, 2003.

8. Tohyama, H., Yasuda, K., Minami, A., Majima, T., Iwasaki, N., Muneta, T., Sekiya, I., Yagishita, K., Takahashi, S., Kurokouchi, K., Uchio, Y., Iwasa, J., Deie, M., Adachi, N., Sugawara, K., and Ochi, M. Atelocollagen-associated autologous chondrocyte implantation for the repair of chondral defects of the knee: a prospective multicenter clinical trial in Japan. J Orthop Sci 14, 579, 2009.

9. Brittberg, M. Autologous chondrocyte implantationtechnique and long-term follow-up. Injury 39 Suppl 1, S40, 2008.

10. Bartlett, W., Skinner, J.A., Gooding, C.R., Carrington, R.W., Flanagan, A.M., Briggs, T.W., and Bentley, G. Autologous chondrocyte implantation versus matrix-induced autologous chondrocyte implantation for osteochondral defects of the knee: a prospective, randomised study. J Bone Joint Surg Br 87, 640, 2005.

11. Gooding, C.R., Bartlett, W., Bentley, G., Skinner, J.A., Carrington, R., and Flanagan, A. A prospective, randomised study comparing two techniques of autologous chondrocyte implantation for osteochondral defects in the knee: periosteum covered versus type I/III collagen covered. Knee 13, 203, 2006.

12. Steinwachs, M., and Kreuz, P.C. Autologous chondrocyte implantation in chondral defects of the knee with a type I/III collagen membrane: a prospective study with a 3-year follow-up. Arthroscopy 23, 381, 2007.

13. Kon, E., Gobbi, A., Filardo, G., Delcogliano, M., Zaffagnini, S., and Marcacci, M. Arthroscopic second-generation autologous chondrocyte implantation compared with microfracture for chondral lesions of the knee: prospective nonrandomized study at 5 years. Am J Sports Med 37, 33, 2009.

14. Marcacci, M., Berruto, M., Brocchetta, D., Delcogliano, A., Ghinelli, D., Gobbi, A., Kon, E., Pederzini, L., Rosa, D., Sacchetti, G.L., Stefani, G., and Zanasi, S. Articular cartilage 
engineering with Hyalograft C: 3-year clinical results. Clin Orthop Relat Res 435, 96, 2005.

15. Horas, U., Pelinkovic, D., Herr, G., Aigner, T., and Schnettler, R. Autologous chondrocyte implantation and osteochondral cylinder transplantation in cartilage repair of the knee joint. A prospective, comparative trial. J Bone Joint Surg Am 85, 185, 2003.

16. Bentley, G., Biant, L.C., Carrington, R.W., Akmal, M., Goldberg, A., Williams, A.M., Skinner, J.A., and Pringle, J. A prospective, randomised comparison of autologous chondrocyte implantation versus mosaicplasty for osteochondral defects in the knee. J Bone Joint Surg Br 85, 223, 2003.

17. Knutsen, G., Engebretsen, L., Ludvigsen, T.C., Drogset, J.O., Grontvedt, T., Solheim, E., Strand, T., Roberts, S., Isaksen, V., and Johansen, O. Autologous chondrocyte implantation compared with microfracture in the knee. A randomized trial. J Bone Joint Surg Am 86, 455, 2004.

18. Harris, J.D., Siston, R.A., Pan, X., and Flanigan, D.C. Autologous chondrocyte implantation: a systematic review. J Bone Joint Surg Am 92, 2220, 2010.

19. Minas, T. Autologous chondrocyte implantation for focal chondral defects of the knee. Clin Orthop Relat Res 391 Suppl, S349, 2001.

20. Holtzer, H., Abbott, J., Lash, J., and Holtzer, S. The loss of phenotypic traits by differentiated cells in vitro, I. Dedifferentiation of cartilage cells. Proc Natl Acad Sci U S A 46, 1533, 1960.

21. Abbott, J., and Holtzer, H. The loss of phenotypic traits by differentiated cells. 3. The reversible behavior of chondrocytes in primary cultures. J Cell Biol 28, 473, 1966.

22. Igarashi, T., Iwasaki, N., Kasahara, Y., and Minami, A. A cellular implantation system using an injectable ultrapurified alginate gel for repair of osteochondral defects in a rabbit model. J Biomed Mater Res A 94, 844, 2010.

23. Niederauer, G.G., Slivka, M.A., Leatherbury, N.C., Korvick, D.L., Harroff, H.H., Ehler, W.C., Dunn, C.J., and Kieswetter, K. Evaluation of multiphase implants for repair of focal osteochondral defects in goats. Biomaterials 21, 2561, 2000.

24. Ara, T., Tokoyoda, K., Sugiyama, T., Egawa, T., Kawabata, K., and Nagasawa, T. Long-term hematopoietic stem cells require stromal cell-derived factor- 1 for colonizing bone marrow during ontogeny. Immunity 19, 257, 2003.

25. Wynn, R.F., Hart, C.A., Corradi-Perini, C., O'Neill, L., Evans, C.A., Wraith, J.E., Fairbairn, L.J., and Bellantuono, I. A small proportion of mesenchymal stem cells strongly expresses functionally active CXCR4 receptor capable of promoting migration to bone marrow. Blood 104, 2643, 2004.

26. Shimode, K., Iwasaki, N., Majima, T., Funakoshi, T., Sawaguchi, N., Onodera, T., and Minami, A. Local upregulation of stromal cell-derived factor-1 after ligament injuries enhances homing rate of bone marrow stromal cells in rats. Tissue Eng Part A 15, 2277, 2009.

27. Kitaori, T., Ito, H., Schwarz, E.M., Tsutsumi, R., Yoshitomi, H., Oishi, S., Nakano, M., Fujii, N., Nagasawa, T., and Nakamura, T. Stromal cell-derived factor 1/CXCR4 signaling is critical for the recruitment of mesenchymal stem cells to the fracture site during skeletal repair in a mouse model. Arthritis Rheum 60, 813, 2009.

28. O'Driscoll, S.W., Keeley, F.W., and Salter, R.B. The chondrogenic potential of free autogenous periosteal grafts for biological resurfacing of major full-thickness defects in joint surfaces under the influence of continuous passive motion. An experimental investigation in the rabbit. J Bone Joint Surg Am 68, 1017, 1986.
29. Mohan, N., Dormer, N.H., Caldwell, K.L., Key, V.H., Berkland, C.J., and Detamore, M.S. Continuous gradients of material composition and growth factors for effective regeneration of the osteochondral interface. Tissue Eng Part A 17, 2845, 2011.

30. Yamane, S., Iwasaki, N., Kasahara, Y., Harada, K., Majima, T., Monde, K., Nishimura, S., and Minami, A. Effect of pore size on in vitro cartilage formation using chitosan-based hyaluronic acid hybrid polymer fibers. J Biomed Mater Res A 81, 586, 2007.

31. Kasahara, Y., Iwasaki, N., Yamane, S., Igarashi, T., Majima, T., Nonaka, S., Harada, K., Nishimura, S., and Minami, A. Development of mature cartilage constructs using novel three-dimensional porous scaffolds for enhanced repair of osteochondral defects. J Biomed Mater Res A 86, 127, 2008.

32. Wakitani, S., Goto, T., Pineda, S.J., Young, R.G., Mansour, J.M., Caplan, A.I., and Goldberg, V.M. Mesenchymal cellbased repair of large, full-thickness defects of articular cartilage. J Bone Joint Surg Am 76, 579, 1994.

33. Beattie, A.J., Gilbert, T.W., Guyot, J.P., Yates, A.J., and Badylak, S.F. Chemoattraction of progenitor cells by remodeling extracellular matrix scaffolds. Tissue Eng Part A 15, 1119, 2009.

34. Reing, J.E., Zhang, L., Myers-Irvin, J., Cordero, K.E., Freytes, D.O., Heber-Katz, E., Bedelbaeva, K., McIntosh, D., Dewilde, A., Braunhut, S.J., and Badylak, S.F. Degradation products of extracellular matrix affect cell migration and proliferation. Tissue Eng Part A 15, 605, 2009.

35. Hamed, S., Brenner, B., Abassi, Z., Aharon, A., Daoud, D., and Roguin, A. Hyperglycemia and oxidized-LDL exert a deleterious effect on endothelial progenitor cell migration in type 2 diabetes mellitus. Thromb Res 126, 166, 2010.

36. Kim, M., Kim, S.E., Kang, S.S., Kim, Y.H., and Tae, G. The use of de-differentiated chondrocytes delivered by a heparinbased hydrogel to regenerate cartilage in partial-thickness defects. Biomaterials 32, 7883, 2011.

37. Hoemann, C.D., Hurtig, M., Rossomacha, E., Sun, J., Chevrier, A., Shive, M.S., and Buschmann, M.D. Chitosanglycerol phosphate/blood implants improve hyaline cartilage repair in ovine microfracture defects. J Bone Joint Surg Am 87, 2671, 2005.

38. Misao, Y., Takemura, G., Arai, M., Sato, S., Suzuki, K., Miyata, S., Kosai, K., Minatoguchi, S., Fujiwara, T., and Fujiwara, H. Bone marrow-derived myocyte-like cells and regulation of repair-related cytokines after bone marrow cell transplantation. Cardiovasc Res 69, 476, 2006.

39. Shen, L.H., Li, Y., Chen, J., Zacharek, A., Gao, Q., Kapke, A., Lu, M., Raginski, K., Vanguri, P., Smith, A., and Chopp, M. Therapeutic benefit of bone marrow stromal cells administered 1 month after stroke. J Cereb Blood Flow Metab 27, 6, 2007.

40. Anderson, D.D., Chubinskaya, S., Guilak, F., Martin, J.A., Oegema, T.R., Olson, S.A., and Buckwalter, J.A. Posttraumatic osteoarthritis: improved understanding and opportunities for early intervention. J Orthop Res 29, 802, 2011.

41. Jung, Y., Wang, J., Schneider, A., Sun, Y.X., Koh-Paige, A.J., Osman, N.I., McCauley, L.K., and Taichman, R.S. Regulation of SDF-1 (CXCL12) production by osteoblasts; a possible mechanism for stem cell homing. Bone 38, 497, 2006.

42. Nehrer, S., Spector, M., and Minas, T. Histologic analysis of tissue after failed cartilage repair procedures. Clin Orthop Relat Res 365, 149, 1999.

43. Abarrategi, A., Lopiz-Morales, Y., Ramos, V., Civantos, A., Lopez-Duran, L., Marco, F., and Lopez-Lacomba, J.L. 
Chitosan scaffolds for osteochondral tissue regeneration. J Biomed Mater Res A 95, 1132, 2010.

44. Kon, E., Delcogliano, M., Filardo, G., Fini, M., Giavaresi, G., Francioli, S., Martin, I., Pressato, D., Arcangeli, E., Quarto, R., Sandri, M., and Marcacci, M. Orderly osteochondral regeneration in a sheep model using a novel nano-composite multilayered biomaterial. J Orthop Res 28, 116, 2010.

45. Hoemann, C.D., Chen, G., Marchand, C., Tran-Khanh, N., Thibault, M., Chevrier, A., Sun, J., Shive, M.S., Fernandes, M.J., Poubelle, P.E., Centola, M., and El-Gabalawy, H. Scaffold-guided subchondral bone repair: implication of neutrophils and alternatively activated arginase- $1+$ macrophages. Am J Sports Med 38, 1845, 2010.

46. Nixon, A.J., Fortier, L.A., Williams, J., and Mohammed, H. Enhanced repair of extensive articular defects by insulin-like growth factor-I-laden fibrin composites. J Orthop Res 17, 475, 1999.

47. Fukuda, A., Kato, K., Hasegawa, M., Hirata, H., Sudo, A., Okazaki, K., Tsuta, K., Shikinami, Y., and Uchida, A. Enhanced repair of large osteochondral defects using a combination of artificial cartilage and basic fibroblast growth factor. Biomaterials 26, 4301, 2005.
48. Cook, S.D., Patron, L.P., Salkeld, S.L., and Rueger, D.C. Repair of articular cartilage defects with osteogenic protein-1 (BMP-7) in dogs. J Bone Joint Surg Am 85 Suppl 3, 116, 2003.

49. Rabbany, S.Y., Pastore, J., Yamamoto, M., Miller, T., Rafii, S., Aras, R., and Penn, M. Continuous delivery of stromal cellderived factor- 1 from alginate scaffolds accelerates wound healing. Cell Transplant 19, 399, 2010.

Address correspondence to: Norimasa Iwasaki, M.D., Ph.D. Department of Orthopaedic Surgery Hokkaido University School of Medicine

Kita 15, Nishi 7, Kita-Ku

Sapporo 060-8638

Japan

E-mail: niwasaki@med.hokudai.ac.jp

Received: July 5, 2011

Accepted: November 18, 2011

Online Publication Date: January 4, 2012 